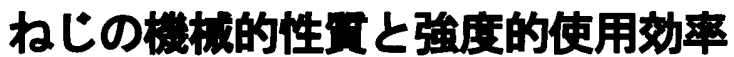

\author{
小林光男 ${ }^{* 1}$, 羽部恭介 ${ }^{* 2}$, 後藤芳樹 ${ }^{* 1}$, 内田靖友 ${ }^{* 1}$
}

\section{Mechanical properties and Strength use efficiency of Screw}

\author{
Mitsuo KOBAYASHI ${ }^{* 1}$, Kyosuke HABU $^{* 2}$,Yoshiki GOTOH ${ }^{* 1}$ Yasutomo UCHIDA ${ }^{* 1}$ \\ *1 Kogakuin University, Department of Mechanical Systems Engineering \\ Nishishinjyuku 1-24-2, Shinjyuku-ku, Tokyo, 163-8677 Japan \\ *2 Hitachi Appliances, Inc., Nishishimbashi 2-15-12 ,Minatołu Tokyo, 105-8410 Japan
}

\begin{abstract}
Although a large number of studies have been made on screw threads, little is known about mechanical screw. The aim of this paper is to improve the reliability of bolted screw joint design by clarifying the relationship between hardness and tensile strength and strength use efficiency of cross recessed pan head mechanical screw. In conclusion, (1) Real tensile strength of mechanical screw products is lower than the value estimated by relational expression, (2) Tightening axial force has a constant limiting value, (3) Strength use efficiency decreases as the nominal diameter becomes bigger.
\end{abstract}

Key Words : Machine element, Small screw, Tigthtening, Mechanical property, Strength use efficiency

\section{1. 楼}

ねじ締結体においてその機能を十分に生かすために は, 使用されるねじに適正な締付け力を与えることが重 要であるが，それを決定することは容易ではない ${ }^{11}$. 機 械構造物及び精密機器などの締結には多くのねじが使 用され，特に電気・電子機器においては小ねじの使用が 多い.一方, 小ねじの使用においては比較的安易な締結 が行われ，機器の搬送中及び使用中に生じる振動・衝慗 によりねじのゆるみなどの軸力低下による使用不能及 び機能低下が問題になっている.

本報告は，小ねじ製品の強度評価について検討したも のである. 先ず，小ねじ製品の硬さ試験及び引張試験に よる機械的性質を求め,ビッカース硬さと引張強さの関 係を調べ，硬さから引張強さの推定の可能性について検 討する. 次に，小私じの締付けを行う作業環境を想定し て，トルク法による締付け試験を行い，小ねじで使用す る締付け軸力と材料が持っている強度を実験的に求め, 強度的使用効率として比較したものである.

\section{2. 实的方法}

\section{1 供試材}

実験に用いたねじ試料は，アルミニウム合金（A5056） 製，純チタン製，鋼（SS400）製，ユニクロメッキ処理 されたの龬（SS400）製小ねじ製品の計 4 種の十字穴付

\footnotetext{
${ }^{* 1}$ 正員, 工学院大学 工学部 機械システム工学科 （广163-8677 東京都新宿区西新宿 1-24-2） E-mail: at73299@ns.kogakuin.ac.jp
}

きなべ小ねじ（図 1 参照）で，呼び径はM3〜M6，ねじ 部長さ L は 30mm のものを使用した.

\section{2 機械的性篗の試験}

\subsection{1 硬さ試験}

硬さ試験は，ビッカース硬さ HV で行い，試験荷重 1N 一定とする．ねじ部を研削及び研磨し，内部の硬さを 3 䉪所測定する．荷重保持時間は $30 \mathrm{sec}$ である.

\subsection{2 製品の引張試験}

供試品のねじを図 2 のように, 少なくともねじの呼び 径と同じ長さの遊びねじ部に引張荷重が加わるように ナット又は適当な治具をはめ合わせ, 軸方向以外の引張 荷重が加わらないようユニバーサルジョイントを取り 付けた後, 軸方向の引張試験を行う. 破断位置に関係な くそのときの最大引張荷重をねじ部の有効断面積で除 して引張強さ $\sigma_{\mathrm{B}}$ を求める.

なお，試験中にねじ山がせん断破壊した場合や，試験 後にナットが指の力で取り外せない場合はダブルナッ トを使用し，はめあい長さを増して再試験をする。

\section{3 締付け試験}

\subsection{1 締付け力と締付けトルク}

図 3 に実験の概略を示す. 楴付け管理方法はトルク法 を用いて行う，压縮型ロードセルに座金を介し，トルク 表示付きプラスドライバーを用いてねじの締付けを行 い，締付け力と楴付けトルクの関係を求める. ひずみゲ ージ変換式ロードセルからデジタル荷重計により締付 け力を求め, 締付けトルクは最大測定値 $4 \mathrm{Nm}$ グリップ 


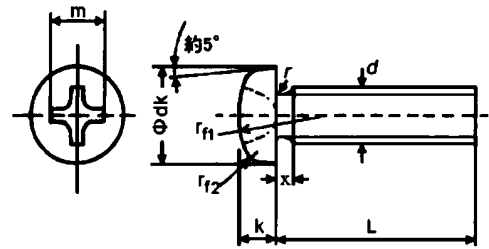

Fig..1 Cross recessed pan head machine screw
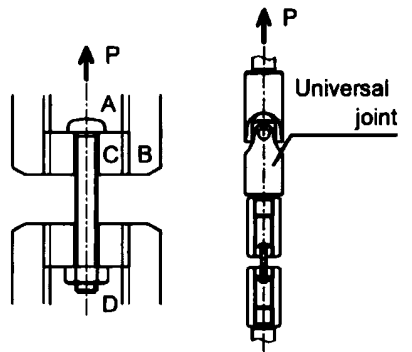

Fig.. 2 State of tensile test

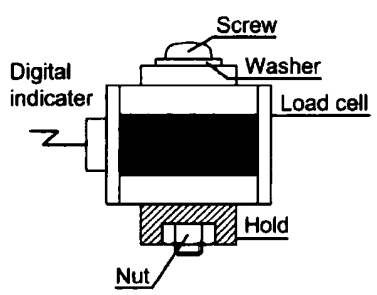

Fig. 3 Tightening test

直径 $37 \mathrm{~mm}$ のトルク表示付きプラスドライバーの值を読 み取る，測定範囲を超えた場合は，最大トルク值 $8 \mathrm{Nm}$ グリップ直径 $42 \mathrm{~mm}$ のものに変更し実験を継続する。

\section{3.2 最大軸力と破壊位圈}

本実験における最大軸力 $\mathrm{F}_{\mathrm{f}}$ max は, 訆験中 (a)ねじ頭部の破 壊，(b)ねじ部の破壊，また(c) 人間が与えることのできる締 付けトルクの限界のいずれかが生じた瞬間の值と定義する. また，そのときの締付けトルクを最大締付けトルク $\mathrm{T}_{\mathrm{f}} \max$ と する. ねじ山がせん断破壊した場合はダブルナットを使用し， はめあい長さを増して再試験をする。

\subsection{3 强度的使用効率}

強度的使用効率とは，締付け試験の結果より得られた最大 軸力を引張試験の結果より得られた降伏点荷重の值で除し割 合で表したものである.

\section{3. 实的果及ひ竞案}

\section{1 小ねじ製品の硬さと引強強さの関係}

硬さ試験及び引張試験の結果を図 4 に示す．図中の式

$$
\sigma_{B} \fallingdotseq 3.27 H V^{3)}
$$

は日本における各種構造用鎆の硬さと引張強さの関係を直線 的に近似したものである ${ }^{4)}$. 本実験で得られた小ねじ製品の 硬さと引張強さの関係を図中の近似式

$$
\sigma_{B}^{*}=2.47 H V+44
$$

に示す. 式(1)より引張強さを推定した場合，実際の小ねじ製 品の引張強さよりも高い值を示すことがいえる，強度が高い 材料ほどその差は大きい.

\section{2 締付け試験による毁大軸力 $F_{\mathrm{f}}$ max}

締付け試験の結果を表 1 及ひ図 5 及ひ図 6 に示寸，材料， 呼び径に関わらず，最大締付け軸力 $\mathrm{F}_{\mathrm{f}} \max$ はほぼ一定の值を
Table. 1 Result of tightening test

\begin{tabular}{c|c|c|c|c}
\hline Material & $\begin{array}{c}\text { Nominal } \\
\text { diamete } \\
\mathbf{r}\end{array}$ & $\begin{array}{c}\mathrm{T}_{\mathrm{f}} \max \\
\mathbf{N} \cdot \mathbf{m}\end{array}$ & $\begin{array}{c}\mathrm{F}_{\mathrm{f}} \max \\
\mathrm{N}\end{array}$ & $\begin{array}{c}\text { Failu } \\
\text { re } \\
\text { part }\end{array}$ \\
\hline Aluminum & M3 & 90 & 580 & $($ a) \\
alloy & M4 & 200 & 1050 & (a) \\
(A5056) & M5 & 360 & 1070 & (a) \\
& M6 & 480 & 1090 & (a) \\
\hline & M3 & 130 & 980 & (a) \\
Pure & M4 & 290 & 1160 & (a) \\
titanium & M5 & 540 & 1170 & (a) \\
& M6 & 800 & 1200 & (c) \\
\hline & M3 & 160 & 1300 & (b) \\
Steel & M4 & 430 & 1320 & (a) \\
(SS400) & M5 & 600 & 1450 & (a) \\
& M6 & 500 & 1490 & (c) \\
\hline \multirow{2}{*}{ Plated } & M3 & 170 & 1280 & (b) \\
Steel & M4 & 250 & 1310 & (a) \\
(S400) & M5 & 620 & 1300 & (a) \\
& M6 & 660 & 1240 & (c)
\end{tabular}

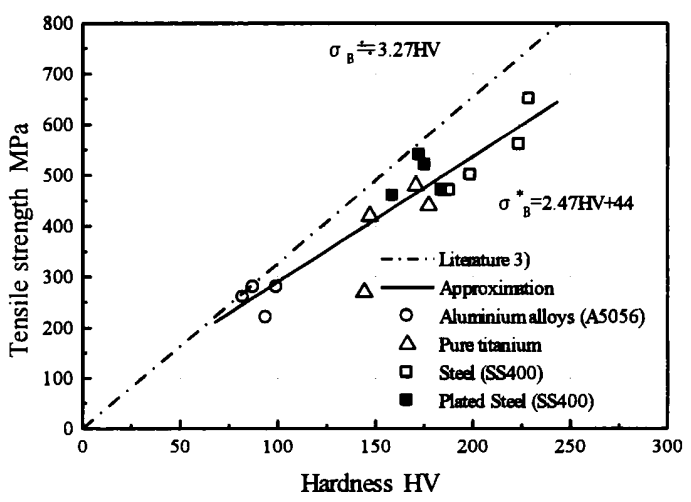

Fig .4 Relationship between hardness and tensile strength
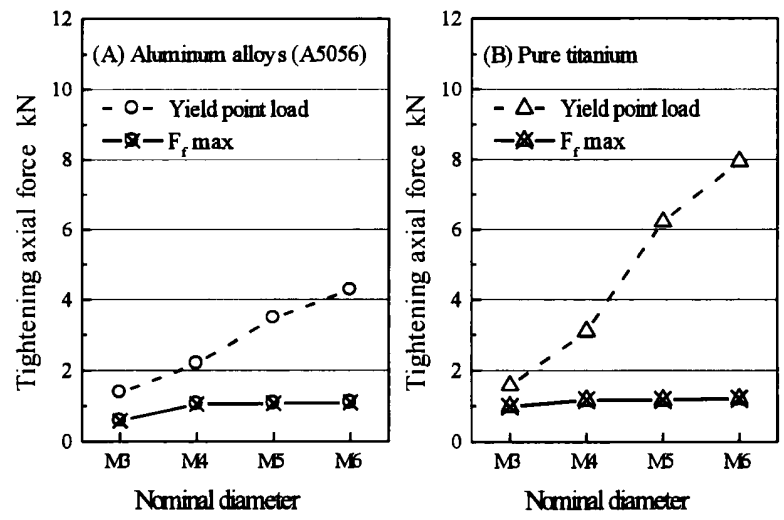

Fig 5. Change of maximum tightening axial force

示している．ねじ部の強度よりもねじ頭部の強度が低いこと が原因と考えられる（表 1参照）。強度の高い純チタン及び 銅製のねじで呼び径M6のものに関しては, 頭部又はねじ部の 

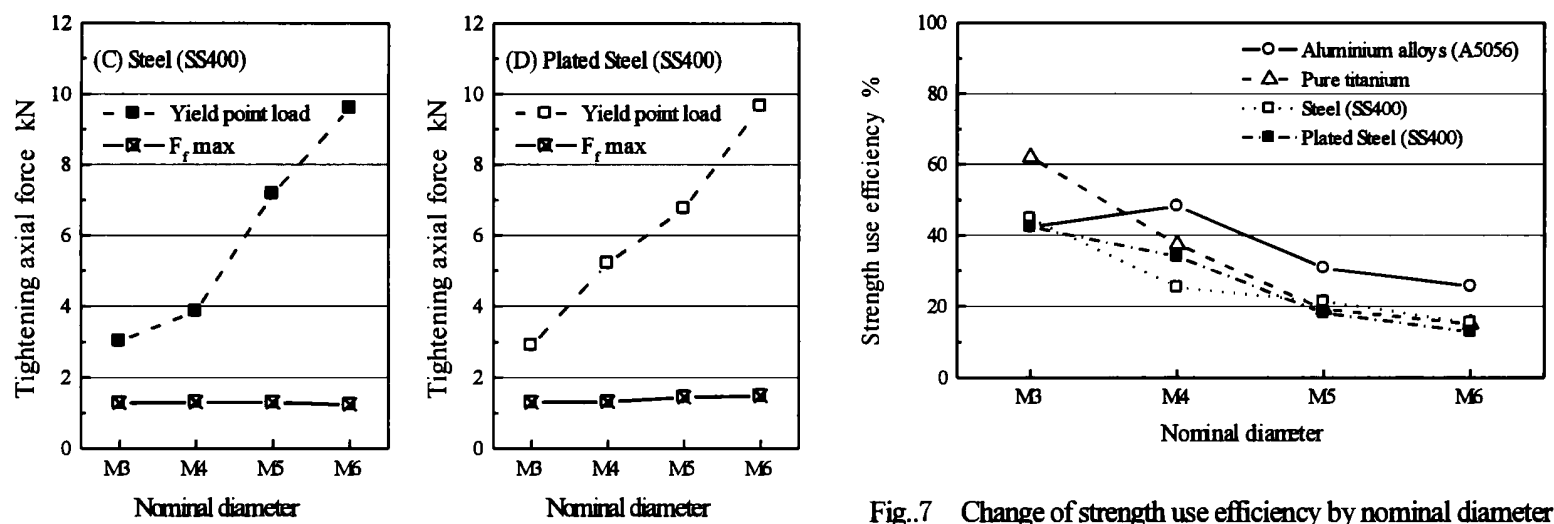

Fig 6 Change of maximum tightening axial force

Fig..7 Change of strength use efficiency by nominal diameter

破壊荷重に達する前にドライバーを用いて人間が与えること のできる締付けトルクの限界に達し, 軸力を一定以上増加さ せることができない.

\section{3 強度的使用效重}

強度的使用効率を図 7 に示寸，呼び径，降伏点荷重が大き い材料ほど強度的使用効率は低下していることがいえる，材 料の強度が高く，サイズの大きい小ねじを選択することはね じの破壊を防ぐことに䡔がるが，使用効率が悪く，ゆるみの 原因にもなる. 図中, アルミニウム合金M3 の使用効率が低い のはねじ頭部の強度が非常に低く，他の材質と異なるためで ある.

\section{4. 耤 百}

以上の各種材料及びサイズの小ねじ製品について機械的 性質を求め, 締付け特性の実験結果から検討を行い主な結論 を次に示す。
（1）硬さより引張強さを推定した場合，実際の小ねじ製品の 引張強さよりも高く評価している.

（2）ねじ頭部の破壊強度がねじ部の破壊強度よりも低い.

（3）材料や呼ひ径に関係なく，ドライバーを用いて与えるこ とのできる締付け軸力には限界があり一定の值を示す。

（4）呼び径が大きくなるにつれ，強度的使用効率は低下する.

参考文献

1）小林光男他: ねじのトライボロジー,トライボロ ジスト, 43-2 (1998)

2）小林光男他: 小ねじの降伏点楴付け, 日本機械学 会論文集, 60-6（2006）

3）山本 普他:ビッカース硬さと引張強さの関係につ いて，材料試験技術，42-3（1997）

4) 吉沢 武男 : 硬さ試験法とその応用，裳華房（1977） 